\title{
The Legacy of Imperialism in Nigeria
}

\author{
Justina Adalikwu-Obisike, PhD \\ Ebere E. Obisike, DHSc \\ Burman University, Alberta, Canada
}

Doi:10.19044/esj.2019.v15n16p229 URL:http://dx.doi.org/10.19044/esj.2019.v15n16p229

\begin{abstract}
At independence in 1960, the colonial rule in Nigeria transformed into neo-colonialism. Nigeria gained political sovereignty through a negotiated settlement that has retained and maintained economic, commercial, and intellectual ties with the ex-colonial administrators and other western nations. Agriculture, which was the economic focus of the colonial administration took a back seat once oil was discovered in commercial quantity in present day Bayelsa state after several failed attempts dating back to 1913. As oil became the main economic attraction in the post-colonial rule, it had various implications for the political economy of Nigeria. Despite attempts to pursue agriculture as a colonial heritage and for the benefit of Nigerians, the discovery of oil in 1956 and the oil boom in the 1970s laid the foundation for Nigeria's dependence on oil as the primary source of its GDP. Using secondary sources and insight from our previous fieldwork in the Niger Delta region, the main argument in this paper is that, imperialism perpetuated the exploitation of agricultural products while its legacy, neo-colonialism has preserved the exploitation of crude oil to the detriments of other economic ventures and the Nigerian masses. Therefore, we posit that the transformation of colonialism into neo-colonialism in Nigeria has resulted in desperation for Nigerians as this arrangement gives power without responsibility and exploitation without redress.
\end{abstract}

Keywords: Neo-colonialism, Imperialism, Exploitation of agricultural products, Colonial legacy, exploitation of crude oil

\section{Introduction:}

At independence in 1960, the colonial rule in Nigeria transformed into neo-colonialism. The political sovereignty of Nigeria was established based on an arrangement that ensured the retention and maintenance of economic, commercial, technical, and intellectual ties with the ex-colonial administrators and other western nations. Since the first exportation of crude oil in 1958 out 
of Port Harcourt, foreign participation in the Nigerian extractive industry has been very extensive. The multinational corporation's invasion of the country's oil industry is not a surprise as the newly independent state lacked the technology and knowledge in the field of oil exploration and extraction.

This lack of technical know-how has not changed significantly, after six decades of oil exploration and extraction in Nigeria. Lacking expertise and extensive capital resources in the extractive industry eventually led to a joint venture by the Nigerian nation and some foreign oil companies. This arrangement, right from the start, negated the place of the local citizens and their reliance on agriculture. Lacking tangible assets that contribute to any meaningful quality of life, the majority of Nigerians have become severely impoverished despite attempts by the political class to diversify the economy, using oil money.

Our main argument is that the transformation of colonialism into neocolonialism in Nigeria has resulted in desperation for most Nigerians. Although the colonial administration did not bequeath a diversified economy to Nigerians at independence, oil replaced agriculture as the primary source of income. In other to achieve the primary objective of this paper, we will briefly talk about neo-colonialism in Nigeria as a colonial legacy, the political economy of Nigeria, and, borrowing from Nkrumah (1965), we argue that, a nation that is in the grip of neo-colonialism is not a master of its destiny.

\section{Methodology}

To achieve the objectives and support the thesis of our paper, we made use of secondary sources and insight from our previous field work in the Niger Delta region that took place between 2004 and 2014. These field works made use of both qualitative and quantitative research design, focusing more on qualitative analysis, wich was appropriate for this paper. The review of literature on Nigeria coupled with information and observations from our previous fieldwork, support our thesis that while imperialism perpetuated agricultural exploitation, neo-colonialism has conserved crude oil exploitation that negates national development and the wellbeing of the masses. We also made use of Nkrumah's 1965 perspective of neo-colonialism in our analysis of the subject of this paper to support our argument that the Nigerian nation is practicing the worst form of imperialism, known as neo-colonialism. To further strengthen our discussion, we also adopted the Leninist analysis of imperialism as a system that is oriented towards economic exploitation. From the above framework, use of secondary sources, and insights from our previous field work, our conclusion from the following discussions and analysis is that the practice of neo-colonialism in Nigeria has given power to a few elites without responsibility while the masses suffer from their exploitation without redress. 


\section{Discussion and analysis:}

Our analysis of the subject matter of this paper will focus on a-two prong discussion; 1) neo-colonialism as a colonial legacy in Nigeria and 2) the political economy of Nigeria. The aim in this section of our paper is to show that neo-colonialism in Nigeria disenfranchises the masses without redress and gives power to the elite without responsibility.

\section{Nigerian colonial legacy: neo-colonialism}

Colonialism in Nigeria was a practice of domination in which the British imperial state subjugated the kingdoms that were amalgamated in 1914, to become present-day Nigeria. Colonialism in Nigeria was a combination of its two forms; a colony of settlement and a colony of the ruled, whereby, the British colonial administrators usurped the power of the coastal chiefs to facilitate the exploitation of natural resources and cheap labour in Nigeria for the benefit of the British Empire (Adalikwu, 2007). Given the unique practice of colonialism in Nigeria particularly after the amalgamation, we argue that imperialism was the predominant practise in this area. Colonialism and imperialism, although not quite the same, have been used synonymously by various scholars (Kohn, 2010). It is also noted by Middleton and Calder-Miller (2008) that, the establishment of legislative influence in a given area by one group over another, is a type of imperialism. Although Britain did not integrate Nigeria as its territory, its administrators were sent to set up their government and economic structures in Nigeria. To this end, we chose to appropriate the concept of imperialism in our argument in this paper, because of the indirect form of domination that was practised, through the indirect rule system. Also, the Leninist analysis of imperialism as a system is oriented towards economic exploitation (Kohn, 2017), which is also a focus of this paper.

After 1914, Nigeria was not much of a colonial settlement but a contraption whereby, the British colonial administrators indirectly exercised the everyday governing activities through the local leaders, who paid tribute to the imperial sovereignty. Imperialism in Nigeria was organised to enable Britain to expand its markets and access cheap labour and raw materials for its benefits through the control of the political and economic devices. Since the principle of neo-colonialism is to ensure that a newly independent nation remains incapable of development while it's political, commercial and financial systems remain tied as in the colonial era, we argue that the indirect rule system that was practised by the British colonial administrators laid the foundation that has facilitated neo-colonialism in Nigeria to date. Consequently, neo-colonialism in Nigeria is perpetuated by the politicoeconomic elites, who use the government machinery to regulate Nigerian internal and foreign policies, to carter to international demands and dictates, and, for their personal selfish agendas and aggrandisement. 
Reading the work of Nkrumah (1965), one will understand that colonialism has not been entirely abolished. Instead, it has been replaced by neo-colonialism. The principle behind this type of a contraption according to Nkrumah (1965: 1) is that the nation that 'is subject to imperialism, is, in theory, independent and has all the outward trappings of international sovereignty but in reality, its economic system and by extension, its political policy is directed from outside.' As noted in Nkrumah's (1965) work, the nation exercising power over the other does not necessarily have to be the one that formerly colonised it. This observation fits the Nigerian case as Britain is no longer the only, or main country that controls the policies and economic activities in Nigeria. Nkrumah (1965: 1-2) further noted that the use of foreign capital for the exploitation of the less developed nations rather than for their development is one of the outcomes of neo-colonialism. Supporting the argument that Nkrumah (1965) made decades ago, the International Financial Institutions Advisory Commission (IFIAC) assessment of the role and effectiveness of the World Bank, the International Monetary Fund, and other financial institutions found that these institutions were not effective rather, constituted problems to the economic growth of the developing countries they claim to assist. For example, Eiras (2003:4) noted that 'the observation and conclusion from the IFIAC assessment of these financial institutions showed the World Bank's evaluation of its performance in Africa had a rate of $73 \%$ failure in reducing poverty and promoting the creation and development of markets and institutions that will facilitate development.'

According to Nkrumah (1965: 4), 'a nation that is in the grip of neocolonialism is not the master of its destiny.' Nkrumah (1965:4) further observed that 'investment under neo-colonialism increases rather than decreases the gap between the rich and the poor nations of the world and, the rich and poor citizens within these nations.' In support of the thesis for this paper, and borrowing from Nkrumah (1965:3), 'for those who practice this form of imperialism, it means power without responsibility, and for those who suffer from it, it means exploitation without redress' making 'neo-colonialism the worst form of imperialism.' It is, therefore, in this worst form that the Nigerian politico-economic elites are indicted as they use state apparatuses to make policies and economic decisions that benefit their foreign allies and promote their selfish agendas, without any form of accountability.

Documented evidence shows that of most Nigeria men and women in high positions of power, have over the decades used their authorities to make policies that favour foreign interests and they in-turn have consistently syphoned the nation's wealth to foreign bank accounts with impunity, to the detriment of the masses and national development.

With a political and economic framework such as neo-colonialism, national elections like that of April 2011 will become a vehicle in choosing a 
local leader who would completely respond to foreign impositions and dictates. The April 2011 election was labelled the only free and fair election in the history of Nigeria (Babic, 2012) besides the June 12, 1993 presidential elections, resulting in a few cynics arguing that such a label was appropriate as it gave local and international legitimacy to the Jonathan Goodluck's administration. They further claimed that, such elections served as an apparatus for the U.S. (and other foreign interests) in selecting someone who would completely carter to their oil needs given the crisis in most of the oil producing nations in the Middle East at the time, and, 'their insatiable need for oil.' (Ottaway, 2003). The 2019 elections in Nigeria might as well be history repeating itself as the PDP National Publicity Secretary, Kola Ologondiyan on behalf of his party has alleged that 'President Mohammadu Buhari's visit to President Donald Trump at the end of April 2018 was to secure U.S. endorsement for his re-election as Nigerian's president' (Bukola, 2018). The question is, why should the United States (U.S.) endorsement matter to a Nigerian leader? Pham noted that it is because the U. S. government recognises Nigeria's importance to the U.S., that the [Trump] White House invited President Buhari who is not only democratically elected but also represents Africa's most populous country and its largest economy (Premium Times, May 2018). Pham (cited in Vanguard News Paper, 2 May 2018) also noted that 'China, which has a large footprint on the African continent, is the top investor in Nigeria and this fact should get Trump's attention.' It is not just about crude oil but all economic activities that are mortgaged on the altar of neo-colonialism. Another example is the fact that President Trump asked President Buhari to remove all trade barriers to U.S. trade with Nigeria, particularly allowing U.S. agricultural produce into Nigeria (Olorunyomi, 2018) although this stance is at odds with Buhari's known preference for protecting Nigeria's agricultural industry and stopping agricultural imports. Since according to Trump, 'we give Nigeria well over one billion dollars in aid every year', [...] 'so the aid dollar entitles the United States to privileged trade status with Nigeria' (Olorunyomi, 2018), even if these terms of trade negate social and economic developments that will benefit the Nigerian masses.

Ultimately, we argue that neo-colonialism in Nigeria is purely a continuation of imperialism, whereby; the key actors are not necessarily foreigners. Instead, it is a vehicle of self-rule whereby local citizens, their raw materials, cheap labour, and natural resources (in this case, oil and agricultural produce), are managed by indigenous leaders on behalf of foreign interests. Of course, these few local leaders do benefit immensely from this type of contraption. It will, therefore, be fair to argue that, Trump also wants a share of the lucrative business that U. S. may potentially have with Nigeria. To further understand our position that neo-colonialism in Nigeria has resulted in 
negative consequences for most Nigerians, we will briefly talk about the political economy of Nigeria.

\section{The political economy of Nigeria}

The entity that became known as Nigeria was primarily a peripheral commonwealth nation that supplied raw materials to Britain. There was little or no economic development in the country for the benefit of the local people, since the focal point of interest was in the transportation and exportation of goods and raw materials such as tin, peanuts, cotton, cocoa, and rubber to their homeland. The creation of a botanical research station in Lagos by Sir Claude Mcdonald in 1893 did not promote large scale farming; instead, it was a mere academic exercise, which has not profited the country economically (Nwachukwu (2006) cited in Akinyetun, 2018).

There was no diversification in the economy, and agricultural activities were punctuated between 1913 and 1921 because of the First World War and its aftermath (Effoduh, 2015). Given this unique position, the socio-political institutions in Nigeria were not well developed and, in most cases, were ignored by the colonialists. This led to the development of social and political institutions that were rooted in ethnicity, after independence in 1960. Although raw materials were harnessed only for the benefit of the colonisers before independence, various economic activities continued postindependence. These activities included the continuation of agricultural production under the Operation Feed the Nation and Green Revolution schemes in the late 1970s and early 1980s, the support of many manufacturing industries that sprang up after independence, and, the establishment of an iron ore industry in the 1980s, to boost the economy. To further improve the economy, the Federal Government provided additional finance to sectors in the country by establishing banks and financial institutions. In spite of this post-independence economic activities geared towards economic diversification by the Nigerian government and local indigenes, as well as external support by countries such as Britain, U. S. A. and the Soviet Union, the most dramatic economic event that has had a long-term effect on the political economy of Nigeria is the discovery and exploitation of petroleum deposits (Adalikwu, 2007).

Crude oil became Nigeria's largest foreign exchange earner by the late 1960s, replacing cocoa, peanuts, cotton, rubber, and palm products. There was a wide spread hope that the oil boom of the 1970s will transform Nigeria particularly, the Niger Delta region to a modern society with economic and socio-political prosperity. Indeed, there was rapid industrialization as many manufacturing industries sprang up and the economy experienced a rapid growth of about 8 per cent per year making Nigeria, by 1980, the largest economy in Africa (Effoduh, 2015). These economic activities were 
undertaken and financed by the government, often with foreign assistance from countries such as Britain and the United States because of the lack of private capital. Educational institutions were also established to assist in producing skilled personnel that will fill the labour sector.

Unfortunately, there was a glitch in this wave of industrialisation as the economy collapsed in the late 1970s and early 1980s contributing to substantial discontent and conflict between ethnic communities and nationalities. In addition to these predicaments, there was the political pressure to expel more than 2 million illegal workers mainly from neighbouring countries such as Ghana and Cameroon, in early 1983 and May 1985 respectively (Effoduh, 2015).

It should be noted that as expected, the oil boom in the 1970s did set the nation on a path of accelerated economic growth and motivated the government's program of rapid industrialisation. The military regimes of Murtala Muhammad and Olusegun Obasanjo in the early to late 1970s benefited from the oil revenue that accrued to the nation due to the skyrocketing oil prices in the 1970s. Foreign oil companies operated in partnership with the Nigerian government since the oil sector is capital intensive but provides 95 per cent of Nigeria's foreign exchange earnings and about 65 per cent of its budgetary revenues (Effoduh, 2015).

Unfortunately, as noted by Pinto (1987), 'the manufacturing sector whose performance was poor during the oil boom became a casualty with the collapse of the oil boom' due to a lack of access to cheap money to import raw materials while agricultural production was neglected (Adalikwu, 2007). Adalikwu (2007) further noted that the Nigerian economy has, for the most part, depended on petroleum products and the dreams that came with the oil boom of the 1970s and well into the 1980s, which it never realised. Instead, as noted by Saro-Wiwa (1992 cited in Adalikwu, 2007), the oil industry exacerbated socio-economic hardships in the Niger Delta region and created a greater socio-political gulf between the oil producing communities and the Nigerian ruling class as well as several ghost community projects. Simply stated, the oil companies depleted natural resources and increased environmental pollution of the mangrove swamps and farmlands with seepage, spills and fouling the air with black smoke and deadly gases from flare-offs that burned both day and night (Apter, 1998 cited in Adalikwu, 2007).

As the expectations of the oil boom did not materialise, Saro-Wiwa noted that the oil industry brought no benefit, but only hardships, particularly to the Niger Delta region as it did not create any new jobs while the ruling class and oil companies syphoned the profits to foreign accounts, without any returns to the host communities (Saro-Wiwa, 1992 cited in Adalikwu, 2007). However, there has been a definite progression and benefits to the country since 1973 when the Nigerian state commenced a partnership with foreign oil companies 
in the exploration and exploitation of oil by acquiring 35\% shares in the Oil Companies. Apart from benefiting the politico-economic elites, these benefits have not trickled down to most of the masses. For example, most rural community projects existed/exist only in name or on signposts as observed during our 2004 fieldwork in Obagi community of River State where we saw a signpost indicating a hospital, with no hospital building in sight. However, on our return trip in 2014, we saw a cottage hospital in the community. See pictures below:

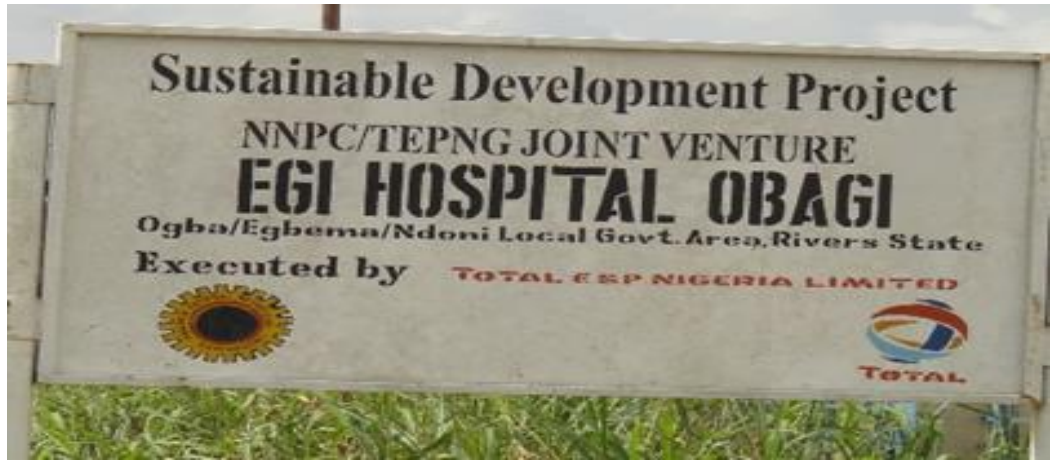

Hospital Sign-post (2004)

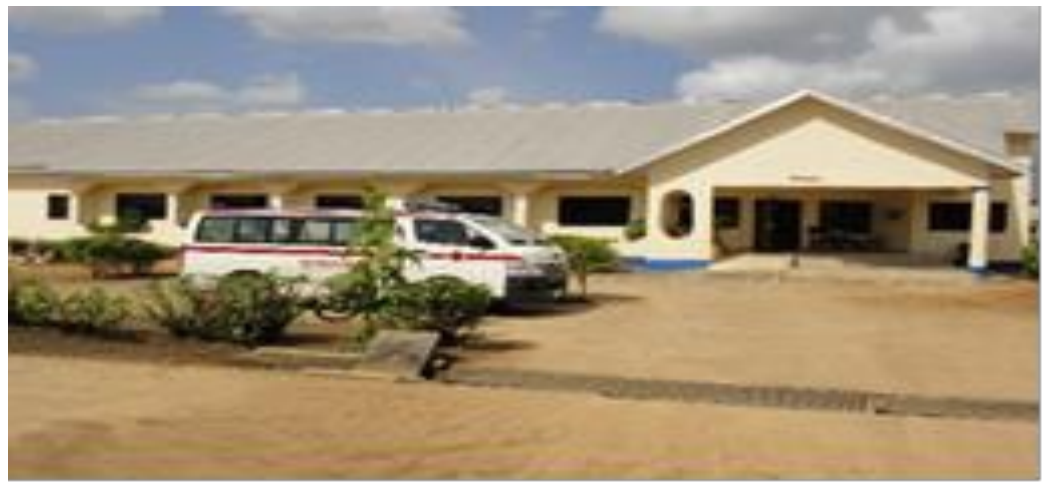

Hospital Building (2014)

The lack of social and economic development explains why Apter (1998) noted that what oil companies brought to the Niger Delta has not profited the indigenes but has polluted the environment, contaminating the mangrove swamps and farmlands with seepage and spills, while fouling the air with black smoke and lethal gases from flare-offs that burned day and night. Corroborating Apter (1998), we also observed gas flares during our 2004 and 2014 fieldwork in the Niger Delta region. See pictures below: 


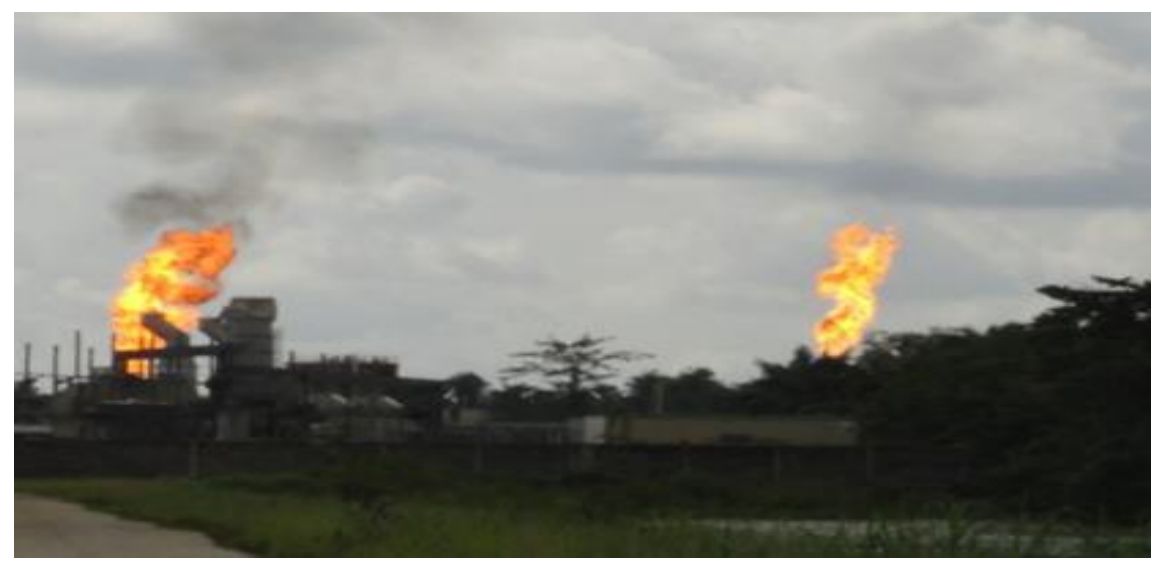

Gas Flare in Obagi (2004)

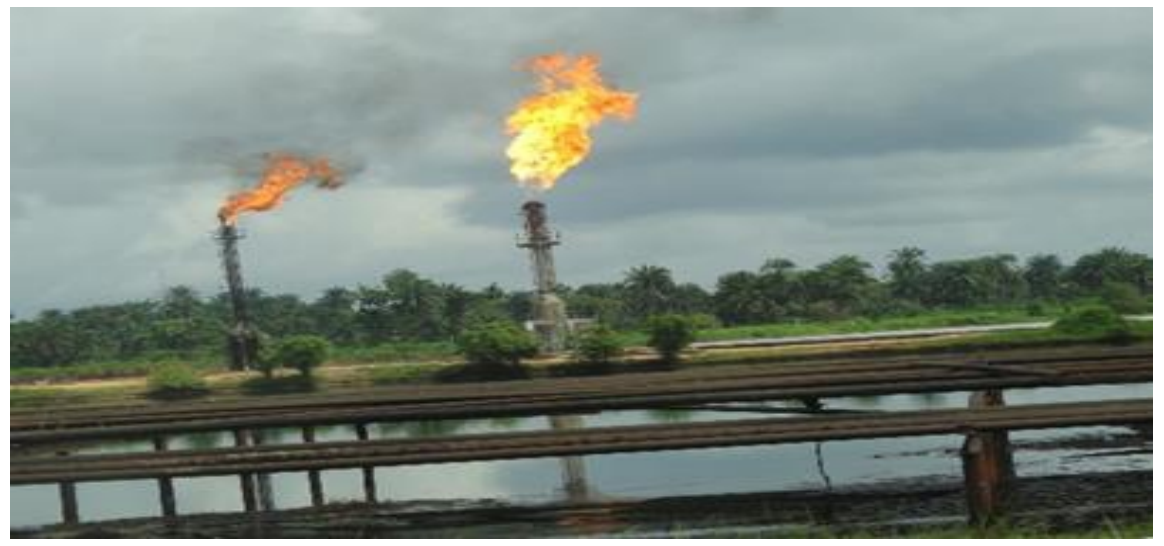

Gas Flare in Omoku (2014)

Reviewing the literature on Nigeria, one will observe that, most indigenes and scholars on the subject have noted that over the years, the political and economic elites have diverted revenue from oil, for their personal use at the expense of the most basic amenities and utilities in the Niger Delta area and other regions in the country. Accordingly, Saro-Wiwa (1992, cited in Adalikwu 2007), stated that oil capitalism has destroyed the Niger Delta region's state of 'nature' by devastating the environment and draining, through its oil pipes the very lifeblood of the people. To substantiate this view, Apter (1998, cited in Adalikwu 2007) observed that most of this area lacked adequate funds for water, roads, health care facilities and primary education. Similar observations were made during our fieldwork in 2004 and again in 2014.

Furthermore, expressing the views of other subjects in our 2004 and 2014 study population, one of the participants stated that, the lack of economic and social development in the area and the general state of poverty in the country has left many in a state of desperation. However, there is enough evidence of the flambuoyant lifestyles of Nigerian politicians. For example, NewsAdmin 
(Sep 24, 2011), noted that 'what some politicians receive as wardrobe allowance can significantly improve the lives of their voters. These days, politicians do not only live in super affluence but, most Nigerians see politics as the easiest way to accumulate wealth. Money that will be used to feed their flambouyant life style and personal agrandisement, like the recent News item about some superrich Nigerians who have formed the habit of ordering Pizza from London to be delivered to them in Nigeria via British airways (Owoseje, 2019).This attitude and behaviour has negated the wellbeing and security of the masses as well as the economic development of the nation.

The sense of insecurity and marginalisation that has engulfed the nation to date became intensified in the early 1980s with the collapse of the international oil market. During this period also, the Nigerian government's spending was no longer commensurate with the accumulation of capital. Hajzler (2000:78) posits that Nigeria has a per capita gross national product of only \$260 US a year, which makes it one of the poorest countries in the world (cited in Adalikwu, 20007). Although the Central Intelligence Agency (U.S.A.) 2017 report shows a per capita GDP of $\$ 5,900$, the socio-economic condition of the masses has not fared better than over a decade ago. Nigeria's federal budget deficit has seen steady growth from 1.951 billion Naira (\$16.26 million US) in 1980 to 6.1 billion Naira (\$50.8 million US) in 1982 . This is the period in which the federal and state governments began to accumulate substantial foreign debts. By 1983, Nigeria's external debt rose to 17.758 billion Naira (\$ 147.98 million US), by which time Nigeria was spending 140 million Naira (\$ 1.17 million US) per month on servicing external debt, resulting in a foreign exchange crisis (NEC, 1984: cited in Adalikwu, 2007). Nigeria's external debt has continued to increase rapidly. For example, the World Debt Tables of the World Bank noted a total outstanding debt of \$19.55 billion US in 1985 and $\$ 23.40$ billion US in 1986 (Chevillard, 2001). The situation is now compounded leading to Chevillard's observation that Nigeria's external debt is the biggest in all sub-Saharan Africa.

The federal government under Shehu Shagari (the president of Nigeria's first republic) enacted an Economic Stabilization Act and declared a state of austerity in the country in 1982. Hit by worsening terms of trade and pressed for more funds, the government entered a negotiation with the International Monetary Fund (IMF) for a standby loan. The government refused to accept the IMF conditions because it included devaluing the Naira. Also, it included a reduction in public expenditure, ordering layoffs, freezing wages, imposing numerous taxes on workers and peasants, commercializing education and health care facilities, increasing export crops production, removing trade barriers, removing subsidies on fertilizers, deregulating prices of petroleum products, and creating a congenial atmosphere for foreign investment by foreign private capital (Adalikwu, 2007). 
Similarly, the military government of Major General Buhari (Nigerian Military Head of State 1983-1985) was also reluctant to succumb to the whole IMF package; however, when retired Major-General Ibrahim Babangida (the Military President of Nigeria 1985-1993) ascended to power after overthrowing Buhari in a military coup in 1985, he vigorously pursued policies along lines approved by the IMF. The whole package came to be known as the Structural Adjustment Program (SAP) and constituted a precondition for securing finances from IMF and World Bank in 1986. Although public opinion was against an IMF loan, Babangida's government was already committed to many of the conditions of the IMF loan including more austere measures. However, pressures to reduce petroleum subsidy to consumers, allow trade liberalisation, and devalue the Naira caved in when Babangida declared a National Economic Emergency on October 1, 1986. With this declaration, the government officially encouraged foreign investment, promoted privatisation and cut back on petroleum subsidies. Despite these drastic measures, efforts to reschedule the foreign debt without an IMF loan failed, and the drop-in world oil prices further compounded Nigeria's unfavourable economic situation. In 1988, the debt was finally rescheduled and, the Nigerian Naira (currency), which had been heavily devalued in 1986, became even more drastically reduced in 1989 and early 1990 (Metz, 1991 cite in Adalikwu, 2007).

The failure of Major-General Babangida's socio-economic and political strategies to resolve the economic crisis among other issues at the time forced him to resign, upon which he appointed Chief Ernest Shonekan as the interim president of Nigeria on August 26, 1993. Preceding this appointment, MajorGeneral Babangida appointed Chief Shonekan as the Head of the Transitional Council of his regime on January 2, 1993, pending a hand-over to an elected democratic leader. It was in this position that Chief Shonekan presided over the June 12, 1993, presidential election that was won by Chief Moshood Abiola and declared by local and international observers as "the freest and fairest" presidential elections in the history of Nigeria. Unfortunately, in a twist of fate, Major General Babangida (retired) annulled the election, and in the aftermath of the political and economic crisis that ensued, the late General Sani Abacha seized power via a military coup in late 1993.

The previous and last military junta to date in the history of Nigeria under General Sani Abacha (1993 - 1999) witnessed an intensification of socioeconomic and political problems that included the undermining and subversion of economic and political procedures, high level of inflation, and double standards, with particular reference to foreign currency exchange which further weakened the manufacturing sector. Abacha's regime was repressive and suffered from fundamental structural defects as the productive and technological base of Nigeria's economy remained weak, outdated, 
inflexible and externally dependent (the Federal Republic of Nigeria, 2000). After almost a decade of Abacha's repressive regime, he died in 1998 and was succeeded by General Abdulsalami Abubakar, who promised to return the country to a civilian rule. Despite the poor economic and political situation, General Abubaker focused on his promise, which he kept by handing over power on May 29, 1999, to President Olusegun Obasanjo who won the January 1999 presidential elections.

Upon assumption in office in the fourth republic in 1999, Obasanjo set in motion to salvage the battered economy that was on the verge of collapse and regain the credibility of the country that was lost during the long years of military rule as the successive military regimes undermined social policy, and the economic and political institutions of the country (Mudasiru and Adabonyon, 2001). Greed and opportunism thrived in the socio-political and economic milieu at the time, and one cannot be wrong in ascertaining that, the policy errors of the past regimes, as was the case with colonial rule, have severely affected the current political economy of Nigeria. Mudasiru \& Adabonyon (2001) assert that notwithstanding Obasanjo's administration flaws, the government took some decisive measures. For instance, it enacted the Anti-corruption bill and started the monitoring of domestic and international campaign to recover looted public assets. Also, it instituted the Petroleum (Special) Trust Fund (PTF), and the introduction of Universal Basic Education among other programmes.

Although the presidential election of 21 April 2007 won by Umaru Musa Yar'Adua was controversial, he was sworn in on 29 May 2007 succeeding Obasanjo. Yar'Adua came to power at a time when most Nigerians had given up hope of an astute and upright leadership, with integrity and decency. His government was pro the generality of the people as opposed to the cabal. Although the odds were stacked against him, Yar'Adua did his best to stabilise the economy against dropping oil prices and decreased production because of the on-going crisis in the Niger-Delta region. Yar'Adua acted according to the rule of law, revamping the country and its economy from the deplorable state his predecessor left it, by fighting corruption without fear or favour. He also initiated a strategy to promote agricultural production. Unfortunately, he did not live long for his excellent leadership style to yield long-lasting results.

Goodluck Ebele Jonathan became the president after Yar'Adua's death in 2010. Although he achieved some economic and socio-political gains using late Yar'Adua's 7 points transformation agenda, his weaknesses as a president are what most would remember. Unfortunately, things went back to how they were, if not worst. There was terror all over the country as Boko Haram regrouped and resumed their terror attacks in full swing coupled with the crisis in the Niger Delta region, heightened fraudulent activities in government and what has become known as cabalisation and corruption with impunity became 
the norm. For example, Opejobi (2017) noted that Olu Ajakaiye, the President of Nigeria Economic Society and a World Bank consultant stated in his Keynote address at the 2017 edition of the Bullion Lecture organised by the Centre for Financial Journalism that, 'Nigeria's economic growth under President Jonathan was fake.' Opejobi (2017) also stated that 'the reason Ajakaiye proffered was that, President Jonathan merely deployed oil revenue into the economy while the socio-economic structures remained disarticulated.'

Then came Mohammadu Buhari, who won the 2015 presidential elections to become the current president of Nigeria. President Buhari's government upon assuming office, promised to fight corruption, revive the economy and security. He got an approval rate of $57 \%$ for his performance on his 3-point agenda at the end of his second year in office. The military has been noted to have performed creditably well in the fight against insurgency although Boko Haram is still very active, and the government has failed to adequately address the menace of the so-called Fulani Herdsmen (Premium Times, n. d.).

It should be noted that Buhari's promise to revive the economy did not yield any tangible result, and the economy has continued to slide into recession after recession, coupled with the fall in the oil prices in the international market and militant groups' activities in the Niger Delta region that has continued to hamper the production of oil. However, in 2016 there was a record growth of $4.11 \%$ in agriculture and $7 \%$ in solid minerals, with the Excess Crude Account showing an inflow of US\$87m, in 2017, among others (Premium Times, n. d.). Whether Buhari will succeed where those before him had failed in steering Nigeria and its citizens onto the path of socio-economic and political development remains to be seen, but now, although he is making in-roads with his 3-point agenda, the Fulani Herdsmen's saga seems set to unravel any gains he has achieved so far.

One can argue that, the political and economic situation in Nigeria since independence has reinforced the power and enriched the lives of some and has threatened the livelihood and impoverished the lives of many others, reinforcing the notion that, imperialism in its new form of neo-colonialism gives power to the rulers without responsibility and exploits and marginalises others without redress.

\section{Conclusion and recommendations}

At the dawn of the entity now known as Nigeria, agriculture was the mainstay of the economy. Nigeria exported farm produce to the home country of the colonial administrators. However, the production of oil in commercial quantity in the late 1950s pushed agriculture to the background while petroleum production and export became the mainstay of the economy' Nigerian National Petroleum Corporation (NNPC). (n.d.). The oil boom of the 
1970s further led to the neglect of agriculture as there was cheap money to import both consumer goods and raw materials and thus, creating a false sense of self-sufficiency.

Adeyeri and Adejuwon (2012) noted that, 'although the colonial authority had no interest in the socio-political and economic development of Nigeria except the exploitation of raw materials and agricultural products for the benefit of imperial Britain,' there was a concerted effort by the new indigenous leaders at the dawn of independence to develop and diversify the economy. Supported by the oil boom money, infrastructures were put in place to enable economic development. Despite the legacy of imperialism as discussed in this paper, and the hindrance of economic growth by the protracted military rule, corruption and mismanagement, Nigeria will eventually actualise its full economic potential given the restoration of democracy and economic reforms.

According to Nigeria's National Planning Commission (Dec. 2009), 'Nigeria has a bold vision of becoming one of the top 20 economies in the world by 2020.' This strategy can be achieved in the light of Nigeria being a powerhouse on the African continent by its size, coupled with its vast oil wealth that promises potential finance for socio-economic development. Unfortunately, lacking good governance not only in economic terms but also, socio-culturally, constitute a glitch as noted by the World Bank, which observed that no country could attain socioeconomic development without good governance, productivity, and innovation among other things.

Among other recommendations, our suggestions for boosting economic growth in Nigeria, holding the politico-economic elites accountable, and, to enable Nigeria as a nation to be the master of its own destiny instead of still wobbling after 58 years of independence and being grossly indebted to foreign financial institutions including IMF and World Bank, are highlighted below. First, there must be a provision and support for good governance. Creating a good environment for effective governance to our understanding is an essential feature of development as it creates an enabling environment for responsibility and accountability through the provision of infrastructure and social services such as health, education, and security (that is grossly lacking at present). The empowerment of Nigerians from all works of life will also strengthen good governance as those empowered will be able to participate equitably, without fear of repression, in the affairs of the nation and in decisions that shape their lives in more meaningful ways. With the support of the government, there should be a creation of a knowledge base, which will, in turn, drive innovation and creativity that will allow the citizenry and the government to harness the nation's abundant natural and human resources for the development of the economy. Attaining sustainable socioeconomic development will also position the country to compete favourably with other nations. 
The era of politics that bred poverty, waste and corruption because of poor policy choices that have favoured consumption over investment and ineffective state interventions over market provisions should be a thing of the past. Instead, there should be a concerted effort by policymakers to increase the level of productivity in the agricultural sector. Policies that will improve expenditure in agriculture will boost economic growth, which will, in turn, change the social indicators of the economy. If agricultural production enriched Britain during colonialism, it could also enrich Nigeria in the 21st century. Our candid suggestion, therefore, is for the state level government to take advantage of president Buhari's policy that gives funds to the state that encourages agricultural production by implementing any agricultural project. However, that the mainstay of the economy in Buhari's government is agriculture and the same government has not decisively addressed the menace of the Fulani Herdsmen's incessant attacks in Benue state and surrounding environs that are considered the food basket of the nation is ironic. As a result, we suggest that personnel in all levels of governance should desist from mere lip service and implement their laudable policies.

The creation and support of the private sector is also key to economic development. As a result, the government should create an enabling environment through the provisions of micro-finance to private companies and small-scale businesses to ultimately boost employment for the youth and support economic growth. Trade, policy and knowledge collaboration with other countries is also vital to economic development in Nigeria. However, this must be done equitably and not follow the pattern of neo-colonialism as it has been the case, post-independence. Ultimately, the insecurity in the country must be brought under control as we cannot yearn for economic development in an environment that is riddled with security crisis and helpless citizens are killed/massacre by some groups daily. When Nigerians can co-existence peacefully, it will also encourage foreign investors and thereby, boost economic growth.

Although the events of the past decades support our thesis that at the dawn of independence there was a transition from colonialism to neo-colonialism, this does not have to remain the same in contemporary Nigeria. Leaders and followers can make concerted efforts to develop a collectivity that is built on strong economic growth for the benefit of all citizens, regardless of ethnicity and religious affiliation. While the Nigerian oil wealth can be held in trust by the government for its citizens, the gains should be shared equitably for the benefit of civil society. Also, a devolution of power will further strengthen the economy, especially when practised in conjunction with an economy of scale, using comparative advantage between the various states in the federation. Hence, we suggest that power should be given to state governments to 
implement policies and services as well as be encouraged to pursue socioeconomic growth according to each state's resources and social environment.

We believe that the implementations of these recommendations may enable Nigeria to emerge from behind the iron curtain of neo-colonialism and become a master of its destiny while ensuring that those with power will apply it with responsibility and politicians/public service personnel can be held accountable for their actions. From our perspective, the above suggestions will also create an enabling environment, not only for economic growth but also for the equitable distribution of resources.

\section{References:}

1. Adalikwu, J. (2007) 'Globalization and the Uneven Application of International Regulatory Standard: The Case of Oil Exploration in Nigeria'. PhD dissertation, University of Saskatchewan, Saskatoon, Saskatchewan.

2. Akinyetun, T. S. (2018) 'Towards achieving food security in Nigeria: the economic strains and strategies for way forward'. Global Journal of Economics and Finance. 2 (1): 7-23

3. Apter, A. (1998) 'Death and the King's henchmen: Ken Saro-Wiwa and the political ecology of citizenship in Nigeria' in Abdul RasheedNa'Allah (ed), Ogoni's Agonies: Ken Saro-Wiwa and the Crisis in Nigeria. Eritrea: African World Press.

4. Babic, M. (2012) '2011 Nigerian elections: national democratic institute for internationalaffairsfinalreport.' <https://www.ndi.org/sites/default/files/NDI\%20Final\%20Report\%2 0on\%20the\%20Nigeria\%202011\%20Electionsnew_Part1.pdf> accessed 16 April 2019

5. Bukola, K. (2018) '2019: Buhari's visit to Trump, a plot to secure US endorsement forre-election-PDP.' $<$ https://naija247news.com/2018/05/01/2019-buharis-visit-to-trumpa-plot-to-secure-us-endorsement-for-re-election-pdp/> accessed 22 April 2019

6. CentralIntelligence Agency

$<$ https://www.cia.gov/library/publications/the-world-

factbook/rankorder/2004rank.html> accessed 15 April 2019

7. Chevillard, N. (2001) 'Nigeria's external debt: evolution, mix and current issues. Translated by Pius Adesanmi.<https://books.openedition.org/ifra/642?lang=en> accessed 17 April 2019

8. Effoduh, J. O. (2015) 'The economic development of Nigeria from 1914 to 2014' CASADE: Council for Africa Security and Development. 
$<$ http://www.academia.edu/4036100/The_Economic_Development_o f_Nigeria_from_1914_to_2014> accessed 24 March 2019

9. Eiras, A. (2003) 'IMF and World Bank intervention: a problem, not a solution. <https://www.heritage.org/monetary-policy/report/imf-andworld-bank-intervention-problem-not-solution> accessed 22 April 2019

10. Federal Republic of Nigeria. (April 2000) 'Obasanjo's economic direction (1999 - 2000)

11. Hajzler, C. (2000) 'Nigerian Oil Economy: Development or Dependence?' Saskatchewan Economic Journal (3rd edition): 75-94.

12. Kohn, M. (2010) 'Post-colonial theory' in Duncan Bell (ed), Ethics and World Politics. Oxford: Oxford University Press.

13. Kohn, M. (2017) 'Colonialism' The Stanford Encyclopaedia of Philosophy (Revised $2017 \quad$ Edition) <https://plato.stanford.edu/entries/colonialism/> accessed 1 March 2019

14. Metz, H. C. (1992). Nigeria: a country Study. Washington DC: Federal Research Division, Library of Congress. Library of Congress Country Studies (2000) Nigeria: Women's Role <http://lcweb2.loc.gov/cgibin/query/r> accessed 29 March 2019

15. Middleton, J. and J. Calder-Miller (2008) New Encyclopedia of Africa. Detroit MI: Thomson/Gale

16. Mudasiru, S. and O. Adabonyon (2001) 'The Nigerian economy under Obasanjo', Development Policy Management Network Bulletin viii (3): 10-13.

17. NewsAdmin. (2011) 'The Flamboyant Lifestyles of Nigerian Politicians' $\quad<$ http://thestreetjournal.org/2011/09/the-flamboyantlifestyles-of-nigerian-politicians/> accessed 3 March 2019

18. Nigerian National Petroleum Corporation (NNPC). (n.d.) 'History of the NigerianPetroleum Industry' <http://www.nnpcgroup.com/NNPCBusiness/Businessinformation/Oi 1GasinNigeria/IndustryHistory.aspx > accessed 27 March 2019

19. Nkrumah, K. (1965) 'Neo-colonialism, the Last Stage of Imperialism' $<$ https://www.marxists.org/subject/africa/nkrumah/neoolonialism/index.htm> accessed 20 April 2019

20. Olorunyomi, L. (2018) 'Trump to Buhari: "remove all barriers to U.S. trade" $<$ https://www.premiumtimesng.com/news/top-news/266773trump-to-buhari-remove-all- barriers-to-u-s-trade.html> accessed 17 March 2019

21. Opejobi, S. (2017) 'Nigeria's economic growth under Goodluck Jonathan was fake' http://dailypost.ng/2017/04/13/nigerias- 
economic-growth-goodluck-jonathan-fake-world-bank-consultantajakaiye/ accessed 20 March 2019

22. Ottaway, M. (2003) 'Securing oil from West Africa and Latin America: the challenge of internal turmoil', Carnegie Endowment for International Peace: Testimony Prepared for the Hearings on "US Energy Security: West Africa And Latin America, October 20, 2003.

23. Pinto, B. (1987) 'Nigeria during and after the oil boom: a policy comparison with Indonesia', The World Bank Review 1 (3): 419-445.

24. Premium Times.(n.d.) 'Nigeria: 57 percent of Nigerians approve Buhari's performancereport' March 2019

<http://allafrica.com/stories/201705290074.html> accessed 4

25. Premium Times. (2018) 'Nigeria: Trump to Buhari - "remove all barriers to

U.S. trade", <https://allafrica.com/stories/201805020010.html> accessed 4 March 2019

26. Saro-Wiwa, K. (1992) Genocide in Nigeria: the Ogoni tragedy. Lagos: Saros International Publishers.

27. Vanguard News Paper. (2018) 'Buhari's visit to Trump: an independent assessment' $<$ https://www.vanguardngr.com/2018/04/buharis-visit-trumpindependent-assessment/> accessed 4 March 2019 